Article

\title{
Complete Benzene Oxidation over Mono and Bimetallic Pd-Au Catalysts on Alumina-Supported Y-Doped Ceria
}

\author{
Tatyana Tabakova ${ }^{1, *(\mathcal{D}, \text { Lyuba Ilieva }}{ }^{1}$, Petya Petrova ${ }^{1}$, Anna Maria Venezia ${ }^{2}$, \\ Yordanka Karakirova ${ }^{1}$, Leonarda Francesca Liotta ${ }^{2}$ (D) and Georgi Avdeev ${ }^{3}$ \\ 1 Institute of Catalysis, Bulgarian Academy of Sciences, 1113 Sofia, Bulgaria; luilieva@ic.bas.bg (L.I.); \\ petia@ic.bas.bg (P.P.); daniepr@ic.bas.bg (Y.K.) \\ 2 Istituto per lo Studio dei Materiali Nanostrutturati, CNR, 90146 Palermo, Italy; \\ annamaria.venezia@cnr.it (A.M.V.); leonardafrancesca.liotta@cnr.it (L.F.L.) \\ 3 Institute of Physical Chemistry, Bulgarian Academy of Sciences, 1113 Sofia, Bulgaria; gavdeev@ipc.bas.bg \\ * Correspondence: tabakova@ic.bas.bg
}

Received: 30 December 2019; Accepted: 2 February 2020; Published: 6 February 2020

check for updates

Featured Application: Design of well performing and cost-effective mono and bimetallic Pd-Au catalysts for complete benzene oxidation.

\begin{abstract}
The protection of environment and human health stimulates intensive research for abatement of volatile organic compounds (VOCs) in the atmosphere. Complete catalytic oxidation is an efficient, environmentally friendly and economically feasible method for elimination of VOCs. This study aims to design high performing and cost-effective catalytic formulations by exploration of appropriate and economically viable supports. Alumina-supported ceria (30 wt. $\%$ ) and $\mathrm{Y}_{2} \mathrm{O}_{3}(1 \mathrm{wt} . \%)$-doped ceria were prepared by mechanical mixing and were used as support of mono Au (2 wt.\%) and $\mathrm{Pd}(1 \mathrm{wt} . \%)$ and bimetallic Pd-Au catalysts. The characterization by textural measurements, $\mathrm{X}$-ray powder diffraction (PXRD), X-ray photoelectron spectroscopy (XPS), EPR (electron paramagnetic resonance) and temperature-programmed reduction (TPR) was carried out in order to clarify the relationship between catalyst composition, textural, structural and surface properties, reducibility and catalytic performance for complete benzene oxidation. Among all studied catalysts, Pd-based catalysts exhibited the best combustion activity. In particular, monometallic Pd on alumina supported Y-doped ceria attained $100 \%$ of complete benzene conversion at $180^{\circ} \mathrm{C}$. These catalytic materials have potential to meet stringent emission regulations in an economical and effective way.
\end{abstract}

Keywords: Au; Pd and Pd-Au catalysts; alumina-supported ceria; Y-doped ceria/alumina; VOCs oxidation; complete benzene oxidation

\section{Introduction}

Nowadays, environment preserving is one of the major issues facing the world. Alongside with technological progress, human activities contribute to increasing levels of air pollution caused by volatile organic compounds (VOCs). The protection of environment and human health imposes developing of effective strategies for reduction of global VOCs emission. Among the variety of technologies for VOCs removal, complete catalytic oxidation exhibits advantages, making it efficient, environmentally friendly and economically feasible method for elimination of VOCs. Several reviews cover recent progress in research focused on the catalytic oxidation of VOCs, including design of appropriate catalytic systems, their stability and durability, resistance to deactivation, and mechanism of various VOCs destruction [1-5]. Two types of catalysts, in particular, noble metal-based and 
transition metal oxides, are most intensively studied [6]. Significant attention is given to the noble metal-based catalysts, because they demonstrate high activity at low temperatures, better stability and can be regenerated $[7,8]$. Over the past thirty years, supported gold catalysts have exhibited remarkable activity in oxidation of various VOCs and continue to attract the interest of the catalytic community [9-11]. Considerable efforts have been focused on elucidating the effect of preparation methods on gold particle size and oxidation state, role of support effects, relationship between electronic and structural properties of the gold-based catalysts, and catalytic performance. The nature of support has also been highlighted due to its decisive role on the size, shape and amount of supported gold [10]. The proper selection of support is a task of particular importance because in many cases metal oxide is not merely a carrier of gold nanoparticles, but participates actively in reaction mechanism. This observation is especially relevant when supporting material is reducible oxide. In this context, ceria-based systems have received a special attention for VOCs catalytic combustion [12-15]. Unique catalytic properties of ceria originate from its defective chemistry and its ability to exchange rapidly lattice oxygen with the gas phase, thus enhancing catalytic activity at the interfacial metal-support sites. Catalytic performance can be additionally affected by modification of ceria with different metal ions due to improvement of oxygen mobility and reducibility.

Recently, we studied the effect of Y-doping of ceria $\left(1,2.5,5\right.$ and $\left.7.5 \mathrm{wt} . \% \mathrm{Y}_{2} \mathrm{O}_{3}\right)$ on the activity in complete benzene oxidation (CBO) of supported gold catalysts [16]. The best performance $\left(100 \%\right.$ conversion at $\left.250{ }^{\circ} \mathrm{C}\right)$ exhibited gold supported on ceria doped with $1 \mathrm{wt}$. \% $\mathrm{Y}_{2} \mathrm{O}_{3}$ using the impregnation method. Considering the suitability of Pd-based catalysts for low-temperature VOCs oxidation [7,17-19] and special interest in bimetallic Au-Pd system as attractive catalytic material for this reaction [20-22], we compared catalytic behaviors in CBO of $\mathrm{Au}, \mathrm{Pd}$ and $\mathrm{Pd}-\mathrm{Au}$ catalysts supported on ceria and on Y-doped ceria [23]. Pd-Au sample exhibited superior activity (100\% conversion at $150{ }^{\circ} \mathrm{C}$ ) and stability over a period of more than $70 \mathrm{~h}$, which is quite promising behavior in the case of practical application. From an economic point of view, the design of high performing and cost-effective catalyst formulations includes the search for appropriate and economically viable supports. Deposition of highly dispersed particles on high surface area support, in particular, alumina modified by well surface dispersed suitable metal oxide, as this would maximize the activity per mass of noble metal. In this way, having in mind gold catalysts, it is possible to achieve a greater interfacial area between the gold nanoparticles and alumina-supported metal oxides. We have already mentioned the relevance of ceria usage. Modification of alumina with high surface dispersed ceria provides also another advantage - to decrease the amount of ceria in the catalyst formulation as compared to $\mathrm{Au} / \mathrm{CeO}_{2}$. Centeno et al. have reported favorable effect of ceria on activity of $\mathrm{Au} \mathrm{Al}_{2} \mathrm{O}_{3}$ in VOCs complete oxidation [24]. The improved performance of an $\mathrm{Au} / \mathrm{CeO}_{2} / \mathrm{Al}_{2} \mathrm{O}_{3}$ sample was attributed to the role of ceria in stabilization of gold in finely dispersed state, as well as enhanced mobility of lattice oxygen. Gluhoi et al. have also found promotional effect of ceria on catalytic oxidation of propane over $\mathrm{Au} / \mathrm{MO}_{\mathrm{x}} / \mathrm{Al}_{2} \mathrm{O}_{3}(\mathrm{M}: \mathrm{Ce}, \mathrm{Mn}, \mathrm{Co}, \mathrm{Fe})$ [25]. The positive impact of ceria on $\mathrm{Pd} / \mathrm{Al}_{2} \mathrm{O}_{3}$ catalysts has been also demonstrated for the combustion of propene [26].

Considering aforementioned results, we prepared alumina-supported ceria and Y-doped ceria. Following our previous work, these mixed oxides were used as support of mono- and bimetallic Pd-Au catalysts in order to clarify the relationship between catalyst composition and catalytic performance for $\mathrm{CBO}$. Benzene was selected as representative of very stable and difficult to oxidize aromatic molecule, but also because it is toxic, carcinogenic and contributes to the formation of secondary organic aerosols. The developing of catalytically effective and cost-efficient materials could allow meeting stringent emission regulations in an economical and effective way [2]. 


\section{Materials and Methods}

\subsection{Catalyst Synthesis}

Monometallic Au (2 wt.\%) and Pd (1 wt.\%) and bimetallic Pd (1 wt.\%)-Au (2 wt.\%) catalysts were prepared over alumina-supported ceria (30 wt.\%) and alumina-supported Y-doped ceria ( $1 \mathrm{wt} . \% \mathrm{Y}_{2} \mathrm{O}_{3}$ in respect to the amount of ceria). Impregnation (IM) and mechanochemical mixing (MM) were used for synthesis of $\mathrm{CeO}_{2} / \mathrm{Al}_{2} \mathrm{O}_{3}$ and $\mathrm{Y}-\mathrm{CeO}_{2} / \mathrm{Al}_{2} \mathrm{O}_{3}$. The wet impregnation of alumina (Sasol) was carried out with aqueous solution of $\mathrm{Ce}\left(\mathrm{NO}_{3}\right)_{3} \cdot 6 \mathrm{H}_{2} \mathrm{O}$ by stirring at room temperature for $4 \mathrm{~h}$. The water was removed in a rotary evaporator at $70{ }^{\circ} \mathrm{C}$. Then mixed oxides were calcined in air at $400{ }^{\circ} \mathrm{C}$ for $2 \mathrm{~h}$. In order to study the effect of doping with yttrium, the procedure was repeated using aqueous solution of $\mathrm{Y}\left(\mathrm{NO}_{3}\right)_{3} \cdot 6 \mathrm{H}_{2} \mathrm{O}$. The MM route involved: (i) well mixing of alumina and the calculated amount of cerium hydroxide (prepared by precipitation of $\mathrm{Ce}\left(\mathrm{NO}_{3}\right)_{3} \cdot 6 \mathrm{H}_{2} \mathrm{O}$ with $\mathrm{K}_{2} \mathrm{CO}_{3}$ ) and fully grinding for $30 \mathrm{~min}$ in agate mortar; (ii) calcination at $400{ }^{\circ} \mathrm{C}$ for $2 \mathrm{~h}$. Alumina-supported Y-doped ceria solids were prepared by the same way with addition of $1 \mathrm{wt} . \%$ commercial $\mathrm{Y}_{2} \mathrm{O}_{3}$ (Sigma-Aldrich).

Gold-based catalysts were prepared by deposition-precipitation on supports, preliminary subjected to ultrasound treatment in water. The interaction between $\mathrm{HAuCl}_{4} \cdot 3 \mathrm{H}_{2} \mathrm{O}$ and $\mathrm{K}_{2} \mathrm{CO}_{3}$ was carried out at temperature $=60^{\circ} \mathrm{C}, \mathrm{pH}=7$, stirring speed $=250 \mathrm{rpm}$. After ageing at the same temperature within $1 \mathrm{~h}$, the solids were filtered and washed until removal of chlorine ions. Thermal treatment was performed in air at $400{ }^{\circ} \mathrm{C}$ for $2 \mathrm{~h}$. These samples were denoted as $\mathrm{Au} / \mathrm{CeAl}$ and $\mathrm{Au} / \mathrm{CeAl} \mathrm{IM}$ (IM means method of support preparation), and respectively $\mathrm{Au} / \mathrm{YCeAl}$ and $\mathrm{Au} / \mathrm{YCeAl} \mathrm{IM}$ for $\mathrm{Y}$-modified supports. Gold-containing catalysts on ceria $(\mathrm{Au} / \mathrm{Ce})$ and on alumina $(\mathrm{Au} / \mathrm{Al})$ were prepared for comparative purposes. Bare ceria was prepared by precipitation of $\mathrm{Ce}\left(\mathrm{NO}_{3}\right)_{3} \cdot 6 \mathrm{H}_{2} \mathrm{O}$ with $\mathrm{K}_{2} \mathrm{CO}_{3}$ at constant $\mathrm{pH} 9$ and temperature $60^{\circ} \mathrm{C}$, aging of the precipitate at the same temperature for $1 \mathrm{~h}$ and washing until removal of $\mathrm{NO}_{3}{ }^{-}$ions. Then, drying in vacuum at $80^{\circ} \mathrm{C}$ and calcination in air at $400{ }^{\circ} \mathrm{C}$ for $2 \mathrm{~h}$ were carried out.

Pd-containing samples were prepared following the same procedure, deposition-precipitation, as described for gold catalysts, using $\mathrm{Pd}\left(\mathrm{NO}_{3}\right)_{2} \cdot \mathrm{xH}_{2} \mathrm{O}$ as precursor. Based on comparison of catalytic activity of gold-based catalysts (see below in Results), Pd-containing catalysts were synthesized only on supports prepared by MM method. Notation of the samples was $\mathrm{Pd} / \mathrm{CeAl}$ and $\mathrm{Pd} / \mathrm{YCeAl}$. Samples on ceria and alumina were labeled $\mathrm{Pd} / \mathrm{Ce}$ and $\mathrm{Pd} / \mathrm{Al}$, respectively.

Bimetallic Pd-Au catalysts were prepared by sequential deposition-precipitation. Pd was deposited on the preliminary prepared and calcined $\mathrm{Au} / \mathrm{CeAl}$ and $\mathrm{Au} / \mathrm{YCeAl}$ (on MM-prepared oxides). Calcination in air at $400{ }^{\circ} \mathrm{C}$ for $2 \mathrm{~h}$ was repeated after $\mathrm{Pd}$ deposition. The samples were denoted as $\mathrm{Pd}-\mathrm{Au} / \mathrm{CeAl}, \mathrm{Pd}-\mathrm{Au} / \mathrm{YCeAl}, \mathrm{Pd}-\mathrm{Au} / \mathrm{Ce}$ and $\mathrm{Pd}-\mathrm{Au} / \mathrm{Al}$.

\subsection{Catalyst Characterization}

The specific surface areas and the pore volumes were determined from $\mathrm{N}_{2}$ adsorption-desorption isotherms at $-196{ }^{\circ} \mathrm{C}$ using a Micromeritics ASAP 2020. In addition, before the measurements the samples were degassed at $250{ }^{\circ} \mathrm{C}$ for $2 \mathrm{~h}$. The specific surface area was calculated through the Brunauer-Emmett-Teller (BET) method applied to the adsorption curve in the standard pressure range $0.05-0.3 \mathrm{P} / \mathrm{P}_{0}$. By analysis of the desorption curve, using the $\mathrm{BJH}$ method, the pore size distribution was also obtained. The total pore volume $(\mathrm{Vp})$ was evaluated on the basis of the amount of nitrogen adsorbed at the relative pressure of 0.95 . The uncertainty on the estimated values was $\pm 10 \%$.

The phase composition was determined by Powder X-ray diffraction (PXRD) using a PANalytical Empyrean apparatus equipped with a multichannel detector (Pixel 3D) using (Cu K 45 kV-40mA) radiation in the $20-115^{\circ} 2 \theta$ range, with a scan step of $0.01^{\circ}$ for $20 \mathrm{~s}$. The $\mathrm{X}$-ray photoelectron (XP) spectra were recorded with a VG Microtech ESCA 3000 Multilab (VG Scientific, Sussex, UK), equipped with a dual $\mathrm{Mg} / \mathrm{Al}$ anode. The experimental procedure was as already described [23]. The constant charging of the samples was removed by referencing all the energies to the $\mathrm{C} 1 \mathrm{~s}$ set at $285.1 \mathrm{eV}$, arising from the adventitious carbon. Analyses of the peaks were carried out with the software provided 
by VG, based on non-linear least squares fitting program with Lorentzian and Gaussian component curves after background subtraction according to Shirley and Sherwood [27].

The Electron paramagnetic resonance (EPR) spectra were collected at room temperature as a first derivative of the absorption signal of a JEOL JES-FA 100 EPR spectrometer operating in X-band, equipped with a standard $\mathrm{TE}_{011}$ cylindrical resonator. The samples were placed in special quartz reactor and were fixed in the cavity center. The EPR spectra were recorded at following conditions: modulation frequency $100 \mathrm{kHz}$, microwave power $1 \mathrm{~mW}$, modulation amplitude $0.2 \mathrm{mT}$, sweep width $20 \mathrm{mT}$, time constant $0.3 \mathrm{~s}$ and sweep time $2 \mathrm{~min}$.

Temperature-programmed reduction (TPR) measurements were performed in a flow system under the following conditions: $\mathrm{H}_{2}$-Ar gas mixture $\left(10 \% \mathrm{H}_{2}\right)$; temperature ramp rate of $15^{\circ} \mathrm{C} \mathrm{min}^{-1}$; flow rate of $24 \mathrm{~mL} \cdot \mathrm{min}^{-1}$, and sample amount of $0.05 \mathrm{~g}$ [16]. A cooling trap $\left(-40^{\circ} \mathrm{C}\right)$ was installed before the thermal conductivity detector for removal of water (product of reduction). Preliminary calibration of the thermal conductivity detector performed by reducing different amounts of $\mathrm{NiO}$ to $\mathrm{Ni}^{0}$ was used for the calculation of hydrogen consumption during the TPR measurements.

\subsection{Catalytic Measurements}

The catalytic test in $\mathrm{CBO}$ was performed in a flow fixed bed reactor at atmospheric pressure in a temperature range $100-300^{\circ} \mathrm{C}$ under the following conditions: catalyst bed volume $-0.5 \mathrm{~cm}^{3}$, particles size $0.25-0.50 \mathrm{~mm}$, inlet benzene concentration $42 \mathrm{~g} \cdot \mathrm{m}^{-3}$ in air, space velocity $4000 \mathrm{~h}^{-1}$. The products were analyzed by gas chromatograph (Hewlett Packard 5890, Agilent 5890A series II, Germany, working with Agilent G2070 Chemstation Software, Germany) supplied with flame ionization detector and capillary HP Plot Q column, advisable for separation of the eventual products of incomplete benzene oxidation. The catalysts were pretreated "in situ" during $1 \mathrm{~h}$ in a flow of purified air at $350{ }^{\circ} \mathrm{C}$.

\section{Results}

\subsection{Catalytic Activity Measurements}

3.1.1. Effect of Preparation Method of $\mathrm{CeO}_{2} / \mathrm{Al}_{2} \mathrm{O}_{3}$ and $\mathrm{Y}-\mathrm{CeO}_{2} / \mathrm{Al}_{2} \mathrm{O}_{3}$ on $\mathrm{CBO}$ Activity of Gold-Based Catalysts

The benzene conversion as a function of the reaction temperature over gold catalysts, supported on prepared by mechanical mixing and impregnation $\mathrm{CeO}_{2} / \mathrm{Al}_{2} \mathrm{O}_{3}$ or $\mathrm{Y}$-doped $\mathrm{CeO}_{2} / \mathrm{Al}_{2} \mathrm{O}_{3}$, is presented in Figure 1. The reported data refer to complete oxidation, because intermediate products of partial oxidation were not detected.

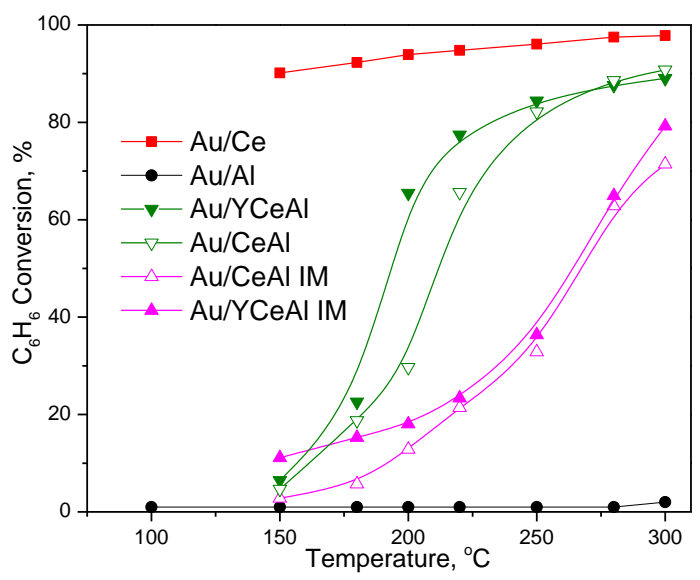

Figure 1. Temperature dependence of complete benzene oxidation (CBO) over gold-based catalysts.

The degree of benzene conversion over $\mathrm{Au} / \mathrm{CeAl}$ was below $10 \%$ at $150{ }^{\circ} \mathrm{C}$. However, it sharply increased after rising the reaction temperature and attained almost $80 \%$ at $220{ }^{\circ} \mathrm{C}$. In contrast, 
the benzene conversion over gold catalyst, supported on prepared by impregnation $\mathrm{CeO}_{2} / \mathrm{Al}_{2} \mathrm{O}_{3}$, i.e., $\mathrm{Au} / \mathrm{CeAlIM}$, showed gradual enhancement with increase of reaction temperature. Finally, this catalyst demonstrated benzene conversion below $80 \%$ at $300{ }^{\circ} \mathrm{C}$. Additionally, results presented in Figure 1 indicated beneficial role of $\mathrm{Y}$-doping of $\mathrm{CeO}_{2} / \mathrm{Al}_{2} \mathrm{O}_{3}$ on activity of gold catalysts. This effect is well visible over gold catalyst on prepared by MM support. It exhibited $63 \%$ conversion at $200{ }^{\circ} \mathrm{C}$, while $28 \%$ conversion was measured in case of gold catalyst on undoped support.

The comparison reveals the favorable effect of mechanical mixing as method for support preparation on $\mathrm{CBO}$ activity of gold-based catalysts. This finding directed our next research step and we used only supports prepared by MM for synthesis of Pd-based and bimetallic Pd-Au samples. For comparative purpose temperature dependences of $\mathrm{CBO}$ over gold catalysts on bare ceria and alumina are also shown in Figure 1. In accordance with many published results, Au/Ce exhibited superior performance, while $\mathrm{Au} / \mathrm{Al}$ was inactive under our reaction conditions. The advantage of the $\mathrm{Au} / \mathrm{Ce}$ sample was not only the high benzene oxidation activity, but also long-term stability within $24 \mathrm{~h}$ at $300^{\circ} \mathrm{C}$.

\subsubsection{Role of the Type of Noble Metal on CBO}

The catalytic performance of gold-based catalysts was described above (Section 3.1.1) and presented in Figure 1.

In Figure 2a are shown the results of CBO over Pd-based catalysts. It is obvious that they perform better than gold-based ones. $\mathrm{Pd} / \mathrm{YCeAl}$ exhibited superior activity. Total benzene conversion was achieved at $180^{\circ} \mathrm{C}$, and no products of mild oxidation were detected within $24 \mathrm{~h}$ test at this temperature. $\mathrm{Pd} / \mathrm{CeAl}$ demonstrated also high activity with $96 \%$ conversion at $180^{\circ} \mathrm{C}$, achieving $100 \%$ conversion at $30{ }^{\circ} \mathrm{C}$. In the presence of yttrium this temperature decreased to $180^{\circ} \mathrm{C}$. It is worth noting the relatively high activity of $\mathrm{Pd} / \mathrm{Al}$ catalyst reaching a maximum conversion of $85 \%$ at $100{ }^{\circ} \mathrm{C}$.

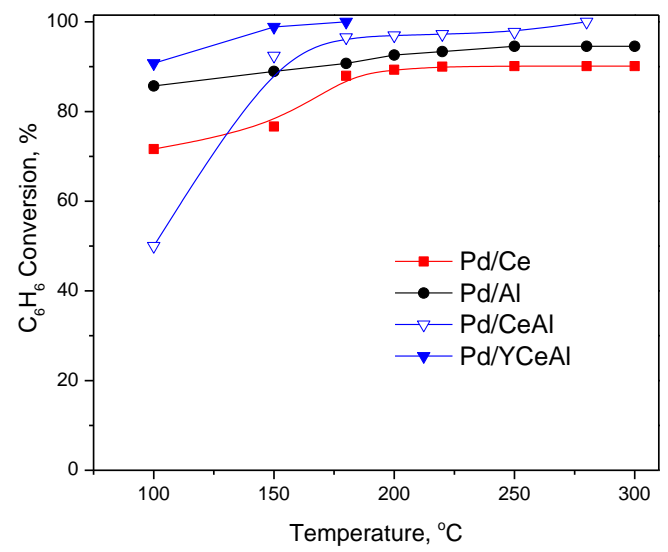

(a)

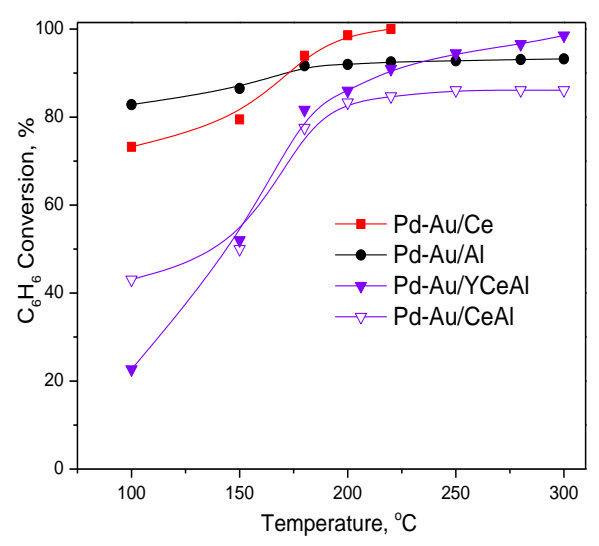

(b)

Figure 2. Temperature dependence of CBO over: (a) monometallic Pd-based; (b) Pd-Au bimetallic catalysts.

With respect to the bimetallic systems, by comparing the results in Figure $2 \mathrm{~b}$ with those in Figure 1, the most significant effect of Pd deposition over gold-based catalysts was observed in case of $\mathrm{Pd}-\mathrm{Au} / \mathrm{Al}$. The addition of Pd in bimetallic Pd-Au systems on CeAl and YCeAl enhanced slightly the activity of gold-based catalysts. However, different from the previously observed superiority of bimetallic formulation [22,23], in this case, their performance could be considered as a combination of the gold-based and Pd-based activity, depending on the temperature interval. In order to separate the effect of the support from the effect of the active metal formulation, in the next section, the conversion curves already shown in Figures 1 and 2 are combined in a new figure where different formulations over each support are discussed. 


\subsubsection{Role of the Nature of Support}

In Figure $3 \mathrm{a}-\mathrm{d}$ the conversions obtained by different catalyst formulations ( $\mathrm{Au}, \mathrm{Pd}$ and $\mathrm{Pd}-\mathrm{Au}$ catalysts) over the same support are compared. Slight positive effect of Pd deposition on benzene oxidation activity above $180^{\circ} \mathrm{C}$ exhibited bimetallic sample supported on pure ceria (Figure 3a). This is the only case for improved performance of bimetallic sample. This catalyst attained $100 \%$ conversion at $220^{\circ} \mathrm{C}$. However, an interesting observation was lower activity of $\mathrm{Pd} / \mathrm{Ce}$ in comparison with $\mathrm{Au} / \mathrm{Ce}$. The results, shown in Figure $3 \mathrm{~b}$ allowed seeing clearly that when alumina was used as support, the activity of bimetallic formulation was due only to the presence of $\mathrm{Pd}$. The degree of $\mathrm{CBO}$ over $\mathrm{Pd} / \mathrm{Al}$ and $\mathrm{Pd}-\mathrm{Au} / \mathrm{Al}$ were the same in the temperature interval studied. Superior performance of Pd-based catalysts on $\mathrm{CeAl}$ and $\mathrm{YCeAl}$ was observed in Figure 3c,d. The comparison demonstrated significantly improved performance of $\mathrm{Au} / \mathrm{CeAl}$ after addition of $\mathrm{Pd}$ (Figure 3c). The conversion of benzene over $\mathrm{Pd}-\mathrm{Au} / \mathrm{CeAl}$ and $\mathrm{Au} / \mathrm{CeAl}$ at $180{ }^{\circ} \mathrm{C}$ was $80 \%$ and $20 \%$, respectively. However, this value remained almost the same for $\mathrm{Pd}-\mathrm{Au} / \mathrm{CeAl}$ with further increase of the temperature up to $300^{\circ} \mathrm{C}$. The favorable role of Y-doping of $\mathrm{CeO}_{2} / \mathrm{Al}_{2} \mathrm{O}_{3}$ is evident in Figure 3d, where the activity of two monometallic and one bimetallic sample on Y-doped CeAl was compared. In this case, enhanced activity of bimetallic formulation was again observed in comparison with gold-based sample. This trend is valid for the entire investigated temperature range.

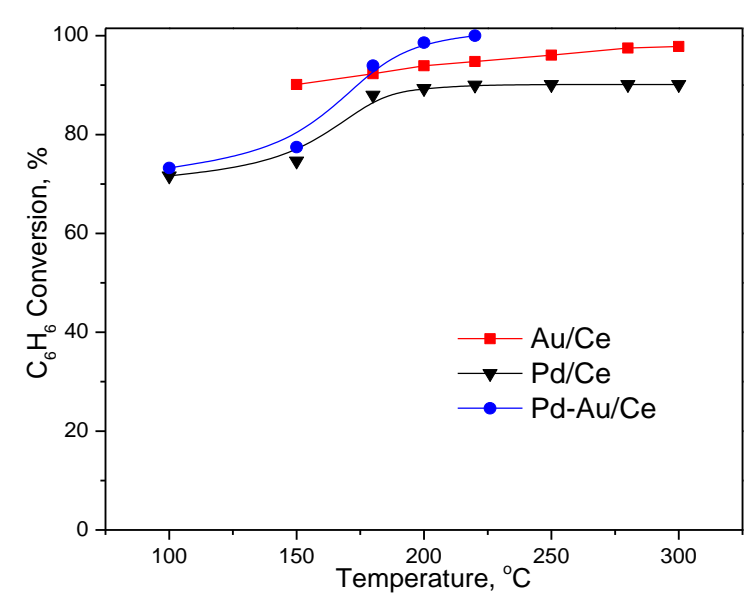

(a)

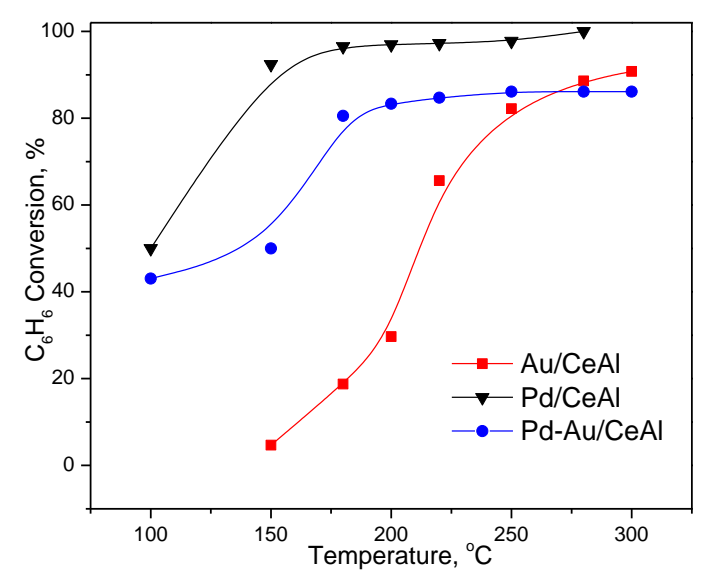

(c)

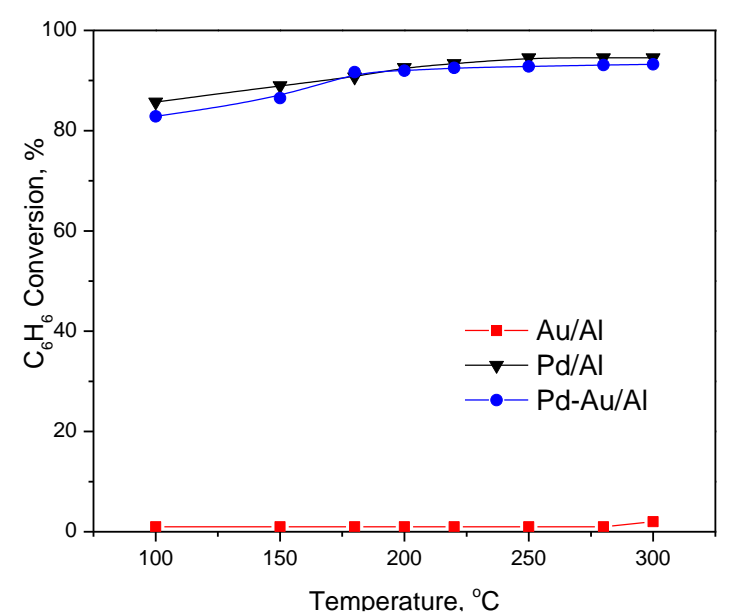

(b)

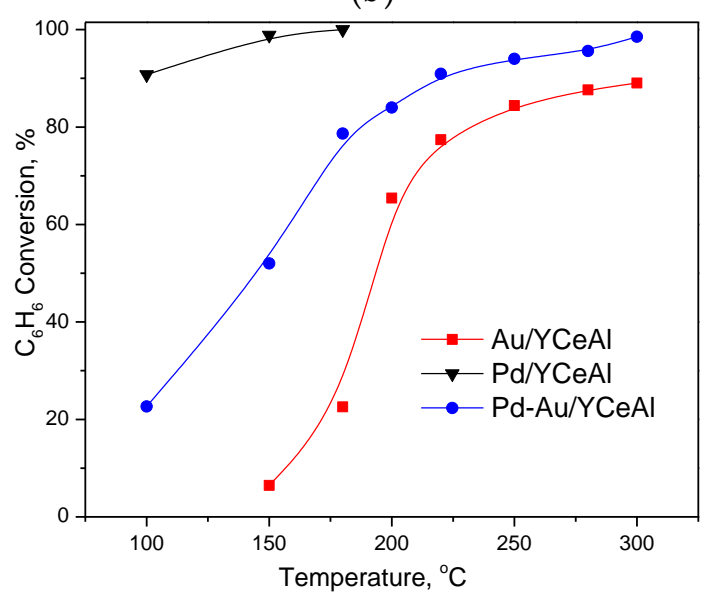

(d)

Figure 3. Temperature dependence of $\mathrm{CBO}$ of different formulations, depending on the support: (a) over $\mathrm{CeO}_{2} ;$ (b) over $\mathrm{Al}_{2} \mathrm{O}_{3} ;$ (c) over $\mathrm{CeO}_{2} / \mathrm{Al}_{2} \mathrm{O}_{3}$ and (d) over Y-doped $\mathrm{CeO}_{2} / \mathrm{Al}_{2} \mathrm{O}_{3}$. 
The activity of $\mathrm{Pd}-\mathrm{Au} / \mathrm{YCeAl}$ gradually increased by increasing the temperature. The conversion of benzene approached $99 \%$, differently from Au/YCeAl that attained only $85 \%$. However, the best performing sample was $\mathrm{Pd} / \mathrm{YCeAl}$, as it was reported above (Section 3.1.2), reflecting both the role of the nature of noble metal and ceria modification by $\mathrm{Y}_{2} \mathrm{O}_{3}$.

\subsection{Catalyst Characterization}

\subsubsection{Textural Properties}

The BET surface areas, pores volume and pores size of the samples supported on pure alumina and ceria are very close to that of the used $\gamma-\mathrm{Al}_{2} \mathrm{O}_{3}$ and $\mathrm{CeO}_{2}$ (Table 1) The same similarity was found for textural characteristics of $\mathrm{Au}, \mathrm{Pd}$ and $\mathrm{Pd}-\mathrm{Au}$ samples, supported on $\mathrm{Ce} / \mathrm{Al}$ and $\mathrm{YCe} / \mathrm{Al}$ prepared by mechanical mixing. However, a significant difference was observed comparing the data of gold-based catalysts on supports prepared by two different methods. The peculiarities driven by the synthesis approach caused lowering of pores volume and pores size when impregnation was applied for preparation of $\mathrm{CeO}_{2} / \mathrm{Al}_{2} \mathrm{O}_{3}$. A decrease of pore volume to $0.28 \mathrm{~cm}^{3} \cdot \mathrm{g}^{-1}$ (CeAl IM and YCeAl IM) in comparison with that of alumina $\left(0.53 \mathrm{~cm}^{3} \cdot \mathrm{g}^{-1}\right)$ occurred. The pore diameter decreased from $10.6 \mathrm{~nm}$ to $8.2 \mathrm{~nm}(\mathrm{CeAl} \mathrm{IM})$ or $8.4 \mathrm{~nm}$ (YCeAl IM). Impregnation method facilitates the penetration of $\mathrm{Ce}^{4+}$ ions into the pores and formation of ceria phase inside the pore structure, thus affecting the access of reagents to the active sites.

Table 1. Specific surface area $\left(\mathrm{S}_{\mathrm{BET}}\right)$, pore volume $\left(\mathrm{V}_{\text {pore }}\right)$, pore size $\left(\mathrm{D}_{\text {pore }}\right)$, average size $\left(\mathrm{D}_{\text {ceria }}\right)$ and lattice parameter $(\alpha)$ of ceria estimated by PXRD.

\begin{tabular}{cccccc}
\hline Sample & $\begin{array}{c}\mathbf{S}_{\mathbf{B E T}} \\
\left(\mathbf{m}^{\mathbf{2}} \cdot \mathbf{g}^{-\mathbf{1}}\right)\end{array}$ & $\begin{array}{c}\mathbf{V}_{\text {pore }} \\
\left(\mathbf{c m}^{\mathbf{3}} \cdot \mathbf{g}^{\mathbf{- 1}} \mathbf{)}\right.\end{array}$ & $\begin{array}{c}\mathbf{D}_{\text {pore }} \\
(\mathbf{n m})\end{array}$ & $\begin{array}{c}\mathbf{D}_{\text {ceria }} \\
(\mathbf{n m})\end{array}$ & $\begin{array}{c}\boldsymbol{\alpha}_{\text {ceria }} \\
(\mathbf{n m})\end{array}$ \\
\hline$\gamma-\mathrm{Al}_{2} \mathrm{O}_{3}$ & 200 & 0.53 & 10.6 & - & - \\
$\mathrm{Au} / \mathrm{Al}$ & 204 & 0.51 & 10.0 & - & - \\
$\mathrm{Pd} / \mathrm{Al}$ & 195.8 & 0.52 & 9.7 & - & - \\
$\mathrm{Pd}-\mathrm{Au} / \mathrm{Al}$ & 193.7 & 0.52 & 9.6 & - & - \\
$\mathrm{CeO}$ & 63.0 & 0.29 & 20.3 & - & - \\
$\mathrm{Au} / \mathrm{Ce}$ & 65.0 & 0.28 & 17.1 & 4.9 & $0.5418(7)$ \\
$\mathrm{Pd} / \mathrm{Ce}$ & 67.6 & 0.28 & 16.5 & 6.2 & $0.5424(4)$ \\
$\mathrm{Pd}-\mathrm{Au} / \mathrm{Ce}$ & 62.5 & 0.29 & 22.5 & 5.1 & $0.5421(7)$ \\
$\mathrm{CeAl}$ & 165.0 & 0.39 & 9.5 & - & - \\
$\mathrm{Au} / \mathrm{CeAl}$ & 147.9 & 0.39 & 9.8 & 6.2 & $0.5426(1)$ \\
$\mathrm{Pd} / \mathrm{CeAl}$ & 161.2 & 0.45 & 9.5 & 5.8 & $0.5424(1)$ \\
$\mathrm{Pd}-\mathrm{Au} / \mathrm{CeAl}$ & 151.6 & 0.37 & 9.6 & 5.6 & $0.5425(1)$ \\
$\mathrm{YCeAl}$ & 168.0 & 0.43 & 10.0 & - & - \\
$\mathrm{Au} / \mathrm{YCeAl}$ & 160.0 & 0.39 & 9.7 & 6.2 & $0.5428(1)$ \\
$\mathrm{Pd} / \mathrm{YCeAl}$ & 166.4 & 0.40 & 9.6 & 5.8 & $0.5420(1)$ \\
$\mathrm{Pd}-\mathrm{Au} / \mathrm{YCeAl}$ & 157.9 & 0.38 & 9.6 & 5.8 & $0.5425(1)$ \\
$\mathrm{Au} / \mathrm{CeAl} \mathrm{IM}$ & $127.0(142 *)$ & 0.27 & 8.6 & 16.8 & $0.5398(1)$ \\
$\mathrm{Au} / \mathrm{YCeAl} \mathrm{IM}$ & $125.0(135 *)$ & 0.27 & 8.7 & 12.6 & $0.5402(7)$ \\
\hline
\end{tabular}

\subsubsection{PXRD measurements}

PXRD analysis was performed for identification of the crystal structure of the catalysts. The average size of ceria $\left(\mathrm{D}_{\text {ceria }}\right)$ and lattice constant $\left(\alpha_{\text {ceria }}\right)$ are listed in Table 1 . Very similar values were measured for all samples, supported on pure ceria and $\mathrm{CeO}_{2} / \mathrm{Al}_{2} \mathrm{O}_{3}$ or Y-doped $\mathrm{CeO}_{2} / \mathrm{Al}_{2} \mathrm{O}_{3}$ prepared by mechanochemical mixing. Significantly larger average crystallite size of ceria (12.6 and $16.8 \mathrm{~nm})$ was calculated in gold-based catalysts on prepared by impregnation supports. Slight contraction of ceria lattice parameter was also observed, that should be related to the size differences. Recently, Reina et al. observed that the increase of crystallites size was accompanied with a decrease in the lattice 
parameter [28]. Partial insertion of some $\mathrm{Al}^{3+}$ in the ceria lattice, because of smaller ionic radius $\left(\mathrm{Al}^{3+}<0.8 \AA, \mathrm{Ce}^{4+}-0.97 \AA\right)$ could be also suggested.

The PXRD patterns are grouped in Figure 4a-d depending on the type of support. As displayed in Figure $4 \mathrm{a}$, four diffraction peaks at $2 \theta=28.5^{\circ}, 33.1^{\circ}, 47.5^{\circ}$ and $56.4^{\circ}$ indicated the presence of $\mathrm{CeO}_{2}$ in the cubic crystal structure of fluorite-type. There were no reflections related to gold or palladium, because of their small amounts and high dispersion. The calculation of the average gold particles size on the basis of High resolution transmission electron microscopy (HRTEM) and high angle annular dark field (HAADF) measurements indicated that despite the support preparation method, the size was very similar $(2-3 \mathrm{~nm})[29,30]$. In contrast, very strong diffraction peaks at $2 \theta=38.2^{\circ}$ and $44,4^{\circ}$ due to the formation of quite big gold particles were observed in the patterns of $\mathrm{Au} / \mathrm{Al}$ and $\mathrm{Pd}-\mathrm{Au} / \mathrm{Al}$ (Figure $4 \mathrm{~b}$ ). The calculated average size was 32 and $40 \mathrm{~nm}$, respectively. The larger size of gold in the bimetallic sample probably was caused by additional thermal treatment at $400{ }^{\circ} \mathrm{C}$ after deposition of Pd.

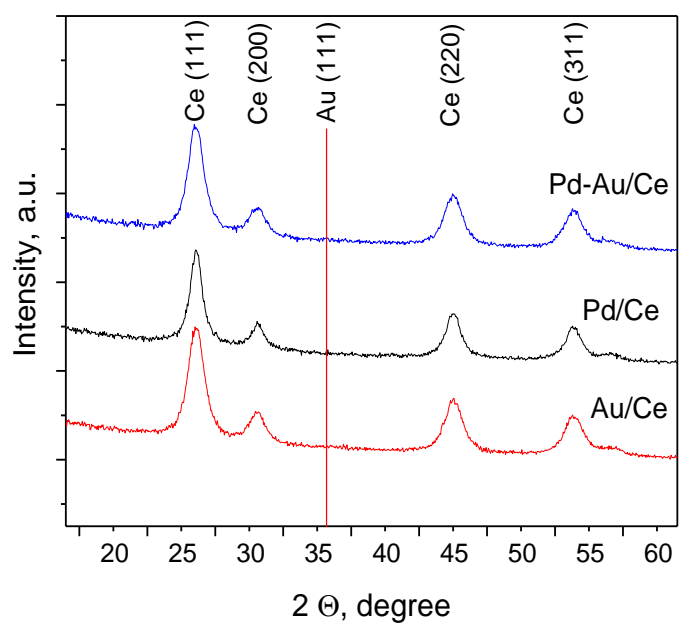

(a)

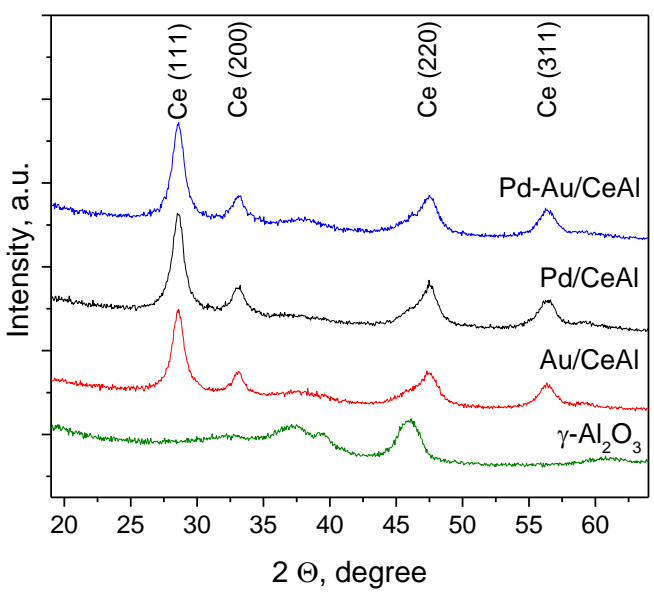

(c)

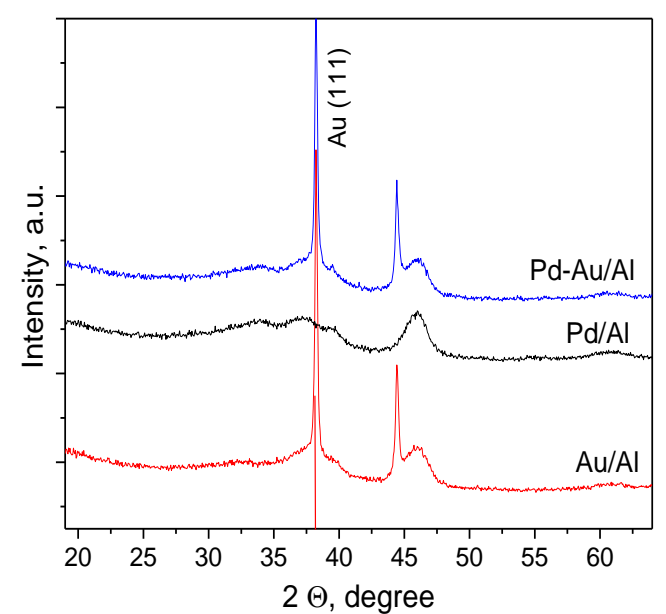

(b)

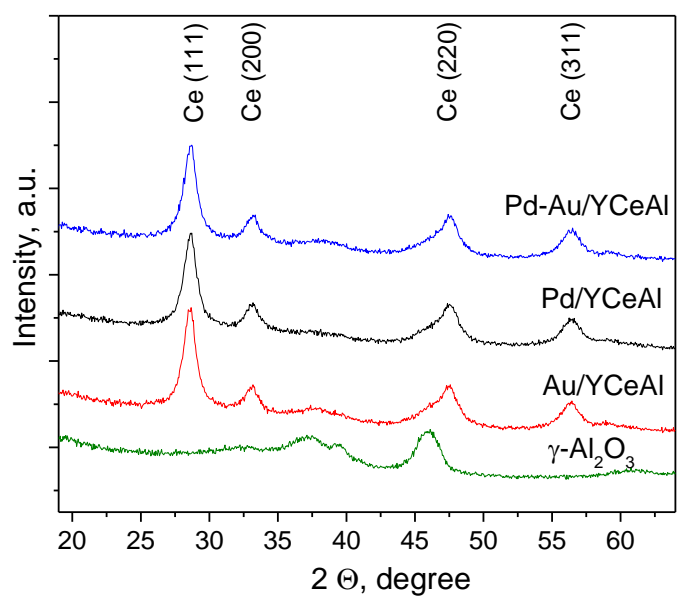

(d)

Figure 4. Powder X-ray diffraction (PXRD) patterns of mono- and bimetallic catalysts supported on: (a) $\mathrm{CeO}_{2} ;$ (b) $\mathrm{Al}_{2} \mathrm{O}_{3} ;$ (c) $\mathrm{CeO}_{2} / \mathrm{Al}_{2} \mathrm{O}_{3}$ and (d) Y-doped $\mathrm{CeO}_{2} / \mathrm{Al}_{2} \mathrm{O}_{3}$.

The peaks of $\mathrm{CeO}_{2}$ dominate in the diffraction patterns of all samples, supported on $\mathrm{CeO}_{2} / \mathrm{Al}_{2} \mathrm{O}_{3}$ or Y-doped $\mathrm{CeO}_{2} / \mathrm{Al}_{2} \mathrm{O}_{3}$ (Figure $4 \mathrm{c}$,d). Weak contribution of alumina is visible about $2 \theta=38^{\circ}$ together with broadening of the ceria peak at $2 \theta=47.5^{\circ}$. $\mathrm{Y}_{2} \mathrm{O}_{3}$ phase was not detected by PXRD. However, 
in very recent studies $[29,30]$, separate $\mathrm{Y}_{2} \mathrm{O}_{3}$ phase was evidenced on the basis of HRTEM and the corresponding Fast Fourier Transforms (FFT) images of gold-based catalysts.

\subsubsection{XPS Measurements}

The XP spectral analysis results are listed in Table 2 . The $\mathrm{Al} 2 \mathrm{p}$ peak was located at binding energy (BE) $75,1 \pm 0.1 \mathrm{eV}$ in the spectra of all samples. The BE of Au $4 \mathrm{f}_{7 / 2}$ peak in the range $84.2-84.5 \mathrm{eV}$ indicated the presence of metallic gold in all gold-containing samples [23]. The $\mathrm{Pd} 3 \mathrm{~d}_{5 / 2}$ spectra of Pd-based samples were characterized by component at $\mathrm{BE}$ around $336.7 \pm 0.1 \mathrm{eV}$, typical of $\mathrm{Pd}^{2+}$, thus excluding the probability of any PdAu alloy formation. The comparison of the XPS derived $\mathrm{Au} / \mathrm{Pd}$ atomic ratio with the analytical ratio (1.1) revealed a surface enrichment of palladium. Quite interesting, the surface segregation of palladium was less in the bimetallic over pure $\mathrm{CeO}_{2}$ support, the only bimetallic formulation that demonstrated better activity as compared to the monometallic ones.

Table 2. X-ray photoelectron spectroscopy (XPS) analysis.

\begin{tabular}{|c|c|c|c|c|c|c|c|c|}
\hline Catalyst & $\begin{array}{c}\mathrm{Ce} 3 d_{5 / 2} \\
(e V)\end{array}$ & $\begin{array}{c}\mathrm{Au} 4 \mathrm{f}_{7 / 2} \\
(\mathrm{eV})\end{array}$ & $\begin{array}{c}\operatorname{Pd} 3 d_{5 / 2} \\
(e V)\end{array}$ & $\begin{array}{c}\mathrm{Y} 3 \mathrm{~d}_{5 / 2} \\
(\mathrm{eV})\end{array}$ & $\begin{array}{c}\mathrm{Au} / \mathrm{Pd} \\
(\mathbf{1 . 1})^{*}\end{array}$ & $\begin{array}{c}\mathrm{Y} / \mathrm{Pd} \\
(0.28) *\end{array}$ & $\begin{array}{l}\text { Y/Au } \\
(0.25) *\end{array}$ & $\begin{array}{c}\mathrm{Ce}^{3+} / \\
\left(\mathrm{Ce}^{3+}+\mathrm{Ce}^{4+}\right)\end{array}$ \\
\hline $\mathrm{Au} / \mathrm{Ce}$ & 882.1 & 84.5 & - & - & - & - & - & 0.30 \\
\hline $\mathrm{Au} / \mathrm{CeAl}$ & 881.9 & 84.3 & - & - & - & - & - & 0.22 \\
\hline $\mathrm{Au} / \mathrm{YCeAl}$ & 881.7 & 84.5 & - & 157.8 & - & - & 1.1 & 0.31 \\
\hline $\mathrm{Pd} / \mathrm{Al}$ & - & - & 336.7 & - & - & - & - & - \\
\hline $\mathrm{Pd} / \mathrm{Ce}$ & 881.7 & - & 337.1 & - & - & - & - & 0.35 \\
\hline $\mathrm{Pd} / \mathrm{CeAl}$ & 881.8 & - & 336.6 & - & - & - & - & 0.25 \\
\hline $\mathrm{Pd} / \mathrm{YCeAl}$ & 881.8 & - & 336.7 & 157.8 & - & 0.21 & - & 0.38 \\
\hline $\mathrm{Pd}-\mathrm{Au} / \mathrm{Al}$ & - & 84.4 & 336.5 & - & 0.21 & - & - & - \\
\hline $\mathrm{Pd}-\mathrm{Au} / \mathrm{Ce}$ & 881.7 & 84.2 & 337.0 & - & 0.46 & - & - & 0.41 \\
\hline $\mathrm{Pd}-\mathrm{Au} / \mathrm{CeAl}$ & 881.9 & 84.2 & 336.7 & - & 0.20 & - & - & 0.29 \\
\hline $\mathrm{Pd}-\mathrm{Au} / \mathrm{YCeAl}$ & 881.7 & 84.3 & 336.7 & 158.2 & 0.18 & 0.23 & 1.2 & 0.33 \\
\hline
\end{tabular}

* The value corresponds to the analytical atomic ratio.

With respect to the $\mathrm{Au} /(\mathrm{Ce}+\mathrm{Al})$ atomic ratios, not listed in the Table 2, a slight decrease from the analytical value of 0.007 to 0.005 was observed in the presence of palladium, probably due to partial covering of gold as a result of sequential palladium deposition over the gold catalysts. On the contrary, with respect to the $\mathrm{Pd} /(\mathrm{Ce}+\mathrm{Al})$ atomic ratios, not listed in Table 2, the highest XPS derived $\mathrm{Pd} /(\mathrm{Ce}+\mathrm{Al})$ atomic ratios of 0.044 and 0.041 as compared to the analytical value of 0.006 were obtained for $\mathrm{Pd} / \mathrm{CeAl}$ and $\mathrm{Pd} / \mathrm{YCeAl}$. These ratios evidence a better surface dispersion of $\mathrm{Pd}$, thus explaining the highest activity of these catalysts. Actually, the highest atomic ratios $\mathrm{Pd} /$ support and $\mathrm{Au} /$ support were observed for $\mathrm{Pd} / \mathrm{Ce}(0.14)$ and $\mathrm{Au} / \mathrm{Ce}(0.06)$ in good agreement with the capability of ceria to well disperse the supported noble metals. The highest activity of $\mathrm{Pd}-\mathrm{Au} / \mathrm{Ce}$ among all bimetallic formulations could be also related to abundance of finely dispersed gold and PdO particles on the surface of ceria.

Important information was received from the ratios $\mathrm{Y} / \mathrm{Pd}$ and $\mathrm{Y} / \mathrm{Au}$. The analysis showed that the atomic ratios $\mathrm{Y} / \mathrm{Au}$ are much larger than the analytical one, whereas the ratios $\mathrm{Y} / \mathrm{Pd}$ are very close to the analytical one (0.28), disclosing the tendency of yttrium to occupy sites close to the palladium.

The analysis of $\mathrm{Ce} 3 \mathrm{~d}$ spectra detected both $\mathrm{Ce}^{4+}$ and $\mathrm{Ce}^{3+}$ oxidation states on the surface of all samples. Based on general agreement about the relationship between concentration of $\mathrm{Ce}^{3+}$ and oxygen vacancies formed for the charge compensation, the atomic ratios $\mathrm{Ce}^{3+} /\left(\mathrm{Ce}^{4+}+\mathrm{Ce}^{3+}\right)$ were calculated and reported in Table 2. The values in the range 0.22-0.41 were higher than the typical values of $0.06-0.10$ for bulk ceria, reflecting defective structure with oxygen vacancies formation on the surface of all catalysts [31]. The highest ratios were observed for the most active samples.

The binding energy of $\mathrm{Y} 3 \mathrm{~d}_{5 / 2}$ at $158.0 \pm 0.2 \mathrm{eV}$ was observed in the spectra of $\mathrm{Y}$-containing samples and attributed to $\mathrm{Y}^{3+}$ [23]. The role of $\mathrm{Y}$-doping on higher defectivity of ceria was also clearly emphasized. The effect was better expressed in case of Pd/YCeAl (0.38) and undoped Pd/CeAl (0.25). 


\subsubsection{TPR}

The reducibility of the catalysts, estimated by TPR, reflects the catalyst oxygen mobility, which is crucial for the Mars-van Krevelen mechanism. The obtained results for monometallic Au and Pd catalysts are compared in Figure 5. TPR profiles of Pd-Au catalysts (not shown) cannot be informative for the role of bimetallic composition because in the presence of hydrogen small paladium and gold particles form non-active inter-metallic species having no effect on the low temperature ceria reducibility. Such behavior was already observed in our previous investigations $[22,23]$ and the decreased surface ceria reducibility was explained by formation of $\mathrm{Au}_{\mathrm{x}} \mathrm{Pd}_{\mathrm{y}}$ alloy particles [22].

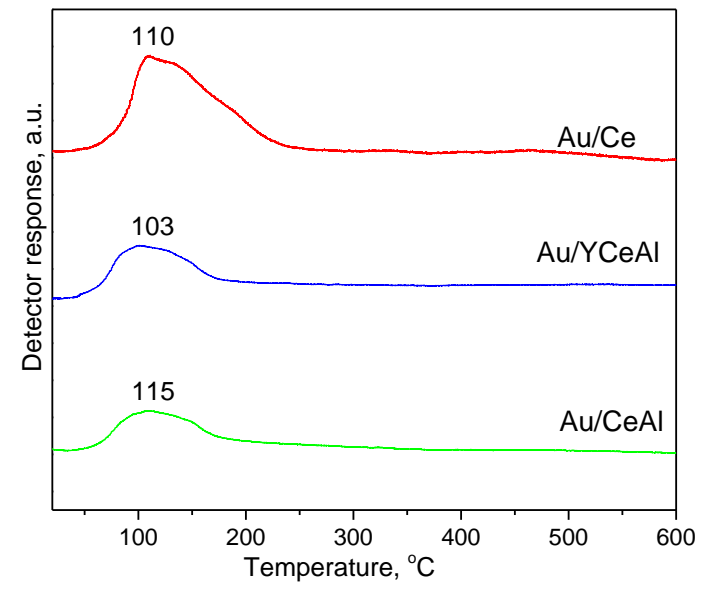

(a)

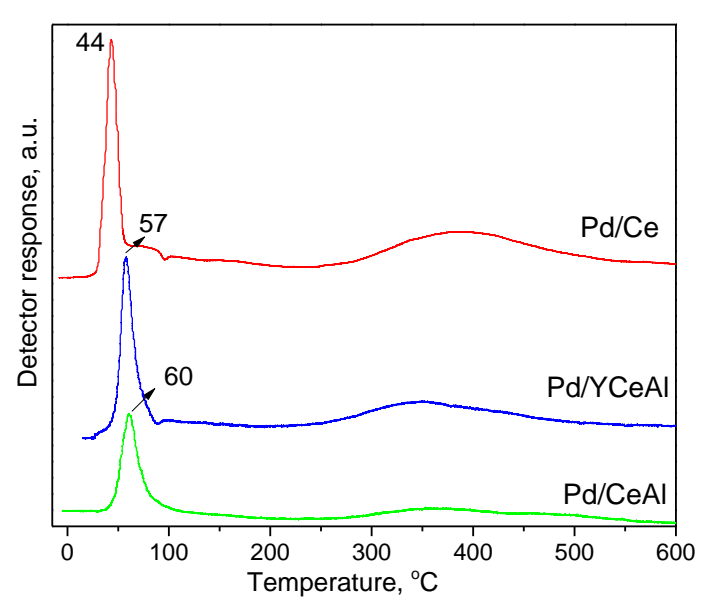

(b)

Figure 5. Temperature programmed reduction (TPR) profiles of: (a) Au-based samples; (b) Pd-based samples.

In Figure 5a are illustrated the TPR profiles of gold-containing catalysts. Reduction was not registered for $\mathrm{Au} / \mathrm{Al}$ sample, because alumina is unreducible oxide and metallic state is characteristic for big gold particles (average size of $32 \mathrm{~nm}$, Table 1). It is already well known that nanosized gold affects the ceria surface layer reduction leading to a significant shift of the position of the TPR peak characteristic for pristine ceria (at around $500{ }^{\circ} \mathrm{C}$ ) towards lower temperatures. The surface ceria reduction of $\mathrm{Au} / \mathrm{Ce}$ was completed up to $250^{\circ} \mathrm{C}$, while TPR peaks finished before $200{ }^{\circ} \mathrm{C}$ in case of alumina-supported $\mathrm{CeO}_{2}$ and $\mathrm{Y}-\mathrm{CeO}_{2}$. The $\mathrm{T}_{\max }$ of the peaks are located at $103-115^{\circ} \mathrm{C}$. The lowest temperature reveals the positive effect of Y-doping. Differently, ceria surface reduction of Pd-containing catalysts (Figure $5 b)$, preceded by reduction of PdO $\left(\mathrm{Pd}^{2+}\right.$ evidenced by XPS analysis, Table 2) to metallic Pd, occurred at very low temperatures $\left(44-60{ }^{\circ} \mathrm{C}\right)$. Broad reduction peaks were also detected in the interval $300-500{ }^{\circ} \mathrm{C}$. A very small negative peak visible in the TPR profiles was attributed to the formation of $\mathrm{Pd} \beta$-hydride that decomposes at about $70-80^{\circ} \mathrm{C}[32,33]$. The catalyst reducibility was also evaluated on the basis of experimental hydrogen consumption (HC) up to $300^{\circ} \mathrm{C}$ which is of interest for the present study of CBO. The calculated values are shown in Table 3. In case of $\mathrm{Au} / \mathrm{Ce}$, the theoretical HC for ceria surface layers reduction without changing the cubic structure $(17-20 \%$ degree of reduction $[34,35]$ ) are $0.49-0.58 \mathrm{mmol} \cdot \mathrm{g}^{-1}$. Having in mind that the initial state of gold in the fresh samples is mainly metallic (XPS analysis), the HC related to gold is negligible and the experimental $\mathrm{HC}$ of $0.54 \mathrm{mmol} \cdot \mathrm{g}^{-1}$ obtained for $\mathrm{Au} / \mathrm{Ce}$ has to be assigned to surface ceria reduction, which is in good agreement with the theoretical values. The HC of $0.26 \mathrm{mmol} \cdot \mathrm{g}^{-1}$ and $0.32 \mathrm{mmol} \cdot \mathrm{g}^{-1}$ respectively, in the case of $30 \mathrm{wt} . \%$ ceria and Y-doped ceria on alumina correspond to $30 \%$ and $37 \%$ degree of reduction (effect of Y-doping). This higher low temperature oxygen accessibility could be achieved for supported ceria phase with structure different from that of the bulk oxide. Though, the total oxygen availability is significantly less as compared to $\mathrm{Au} / \mathrm{Ce}$ catalyst. 
Table 3. Experimental $\mathrm{H}_{2}$ consumption during TPR up to $300{ }^{\circ} \mathrm{C}$.

\begin{tabular}{cc}
\hline Catalyst & HC $\left(\mathbf{m m o l} \cdot \mathbf{g}^{\mathbf{- 1}}\right)$ \\
\hline $\mathrm{Au} / \mathrm{Ce}$ & 0.54 \\
$\mathrm{Au} / \mathrm{CeAl}$ & 0.26 \\
$\mathrm{Au} / \mathrm{YCeAl}$ & 0.32 \\
$\mathrm{Pd} / \mathrm{Ce}$ & 0.43 \\
$\mathrm{Pd} / \mathrm{CeAl}$ & 0.23 \\
$\mathrm{Pd} / \mathrm{YCeAl}$ & 0.29 \\
\hline
\end{tabular}

Concerning $\mathrm{HC}$ for ceria surface layers reduction of Pd catalysts, after subtraction of theoretically calculated $0.09 \mathrm{mmol} \cdot \mathrm{g}^{-1}$ for PdO (1.15 wt. $\left.\%\right)$ reduction, the obtained values are: $0.34 \mathrm{mmol} \cdot \mathrm{g}^{-1}(12 \%$ reduction degree) for $\mathrm{Pd} / \mathrm{Ce}, 0.14 \mathrm{mmol} \cdot \mathrm{g}^{-1}$ ( $16 \%$ reduction degree) for $\mathrm{Pd} / \mathrm{CeAl}$ and $0.20 \mathrm{mmol} \cdot \mathrm{g}^{-1}$ (23\% reduction degree) for $\mathrm{Pd} / \mathrm{YCeAl}$. The differences in the ceria surface layer reduction caused by gold or palladium are well visible: (i) in the presence of gold, the TPR peaks are broader with $T_{\max }$ located about $100^{\circ} \mathrm{C}$. The effect of gold is stronger when the reduction starts at the interface with ceria support. The nanogold particles cause the Ce-O bond strength weakening, easy oxygen vacancies formation and therefore higher oxygen mobility favorable for oxidation reactions. A high temperature tail, better noticeable for $\mathrm{Au} / \mathrm{Ce}$ is due to the less influence of gold, when the process continues far away from the border and the ceria surface layers reduction is completed up to $200-250{ }^{\circ} \mathrm{C}$; (ii) in the presence of $\mathrm{Pd}$ the narrow peaks of low temperature reduction are already finished up to $100{ }^{\circ} \mathrm{C}$. However, HC related to ceria surface layers reduction is smaller as compared to Au catalysts and most probably $\mathrm{Ce}^{4+} \rightarrow \mathrm{Ce}^{3+}$ transition for ions which are far from $\mathrm{Pd}^{0}$ particles proceeds at $300-500{ }^{\circ} \mathrm{C}$. Gil et al. [36] also showed a low temperature TPR peak at $50{ }^{\circ} \mathrm{C}$ assigned to the affected by Pd ceria surface reduction followed by further surface reduction at higher temperatures above $300^{\circ} \mathrm{C}$. The ceria oxygen mobility seems strongly improved at closer proximity to the border with $\mathrm{Pd}$ particles, however the contribution of easier $\mathrm{PdO} \leftrightarrow \mathrm{Pd}^{0}$ redox transfer has to be taken into consideration for $\mathrm{CBO}$ activity.

\subsubsection{EPR Investigation}

EPR measurements were carried out over selected samples after catalytic tests in order to shed more insights on their catalytic behaviour. The main purpose of the EPR investigation was to analyse eventual formation of coke on the catalyst surface. In Figure 6 (line a) is shown spectrum of $\mathrm{Au} / \mathrm{YCeAl}$, because this sample demonstrated high benzene oxidation at $300^{\circ} \mathrm{C}$ within $24 \mathrm{~h}$. The products were only $\mathrm{CO}_{2}$ and water, but degree of conversion was $90 \%$. A single EPR line with g factor 2.003, which is characteristic of carbon-centered radical and coke, was recorded. The same signal was seen in the spectrum of $\mathrm{Pd} / \mathrm{Ce}$ (Figure 6, line e) that showed lower activity in comparison with $\mathrm{Au} / \mathrm{Ce}$ (Figure 3a). The formation of coke could be the reason for observed catalyst behaviour. In the EPR spectrum of the best performing $\mathrm{Pd} / \mathrm{YCeAl}$ was registered other line related to carbon-centered radicals with g-value of 2.0023, typical for free electrons (Figure 6, line b). This sample was studied, because after $24 \mathrm{~h}$ in stream some products of mild oxidation were detected. According to Green et al. g-values close to that of free electron are attributed to organic radicals [37]. The EPR lines with g values 2.0054 and 2.0049 were registered in the spectra of $\mathrm{Pd} / \mathrm{YCeAl}$ and $\mathrm{Pd}-\mathrm{Au} / \mathrm{YCeAl}$, respectively, indicating presence of oxygen centered radicals.

Additionally, a line at magnetic field (334-335 mT) with g-value 1.964, assigned to $\mathrm{Ce}^{3+}$, was observed in the spectra of monometallic $\mathrm{Au}$ and Pd samples on alumina supported Y-doped ceria, pointing on the possible role of $\mathrm{Ce}^{3+}$ in $\mathrm{O}_{2}$ activation [38]. It is also worth noting the presence of several lines at lower magnetic field (320-326 mT) with g values from 2.0097 to 2.056 due to the presence of adsorbed superoxo species $\mathrm{O}_{2}{ }^{-}$close to the $\mathrm{Ce}^{4+}$ ions in spectra of some of the most active samples, i.e., $\mathrm{Pd} / \mathrm{YCeAl}, \mathrm{Au} / \mathrm{Ce}$ and $\mathrm{Pd} / \mathrm{Ce}$ (lines b, $\mathrm{d}$ and e) [39]. These oxygen species can be absorbed onto $\mathrm{Ce}^{4+}$ ions or can fill oxygen vacancies. Different EPR signals were registered due to formation of surroundings with different symmetries. A general consensus of opinion exists about 
beneficial role of adsorbed oxygen species in oxidation-reduction reactions [40]. The availability of adsorbed oxygen species was related to the presence of oxygen vacancies that assisted oxygen molecules activation [41]. Reasonably, the intensity of these lines was the stronger in the spectra of $\mathrm{Au} / \mathrm{Ce}$ and $\mathrm{Pd} / \mathrm{Ce}$, i.e., the samples with highest amount of ceria.

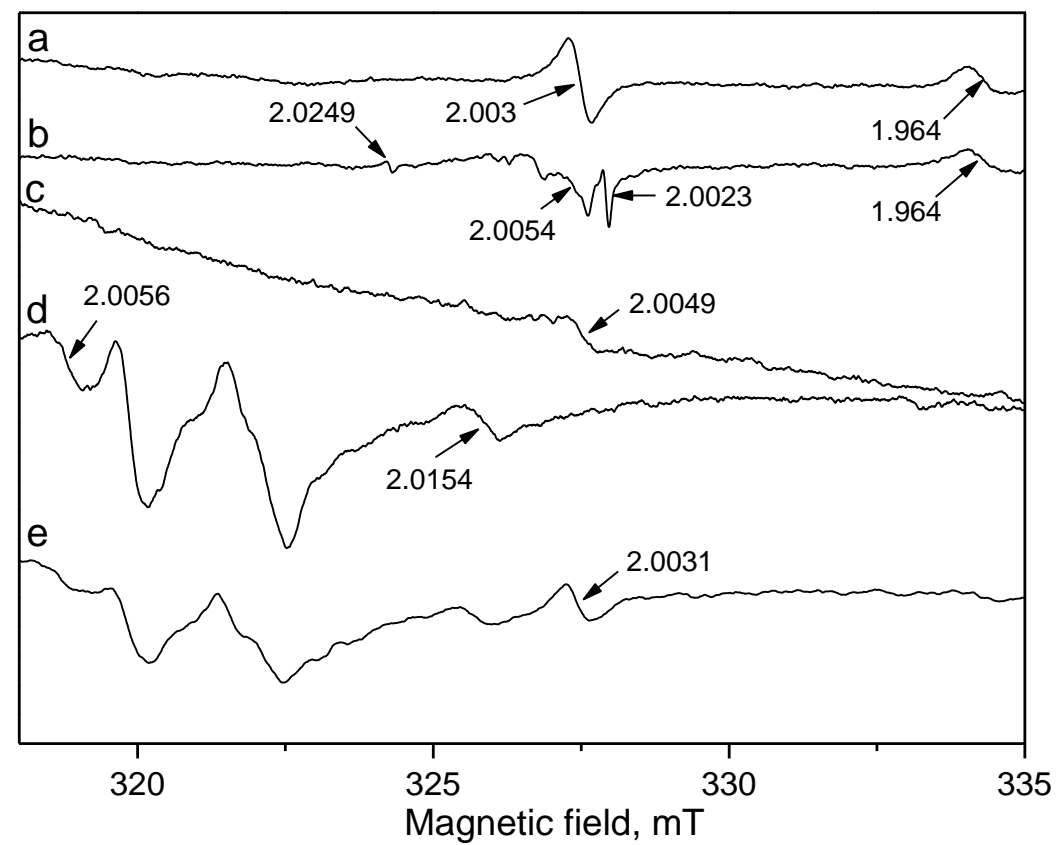

Figure 6. Electron paramagnetic resonance (EPR) spectra of samples after catalytic test: (a) Au/YCeAl; (b) Pd/YCeAl; (c) Pd-Au/YCeAl; (d) Au/Ce and (e) Pd/Ce.

\section{Discussion}

Generally, the catalytic activity of $\mathrm{Au} / \mathrm{ceria}$ catalysts for VOCs oxidation is associated with the weakening of Ce-O bond [14]. The effect is stronger at the interface with gold, where the formation of oxygen vacancies is favored and consequently the surface oxygen mobility of ceria is enhanced. Resulting loosely bonded surface lattice oxygen and easy formed anion vacancies have been proposed as sites of oxygen adsorption and activation, favoring the oxygen supply in VOCs oxidation [10]. The promoted reactivity by Ce-O bonds weakening and easy oxygen vacancies formation can be also related to the ability of the formed oxygen vacancies to affect the binding energy between the catalysts and the reactant molecules lowering the energy barrier for their activation [42] and references therein.

Aiming the exploration of appropriate and economically viable supports as a relevant approach to preparation of high performing and cost-effective formulations we applied impregnation or mechanical mixing for deposition of nanosized ceria or Y-doped ceria on high surface area alumina. Analysis of catalytic tests over gold-based catalysts provided clear evidence of strong effect of $\mathrm{CeO}_{2} / \mathrm{Al}_{2} \mathrm{O}_{3}$ preparation method on $\mathrm{CBO}$ activity. The differences in textural properties (Table 1), in particular, pore volumes and pore sizes, allowed a suggestion of the location of ceria particles inside the pores of alumina using the impregnation method, thus causing some limitations of the access of reactant to the active sites. In contrast, ceria crystallites with a smaller size were located mainly on the surface of alumina by applying mechanochemical mixing. This synthesis approach contributed to improved textural properties that affected $\mathrm{CBO}$ activity of gold-based catalysts on alumina- supported ceria or Y-doped ceria. The favorable role of Y-doping in $\mathrm{CeO}_{2} / \mathrm{Al}_{2} \mathrm{O}_{3}$ mixed support on activity of gold catalysts could be related to improved mobility of oxygen in ceria surface layers. The shift of $T_{\max }$ in the TPR profile of $\mathrm{Au} / \mathrm{YCeAl}$ to lower temperatures as well as slightly higher hydrogen consumption supports this statement. 
At first glance, the higher $\mathrm{CBO}$ activity over $\mathrm{Au} / \mathrm{Ce}$ in comparison with that over $\mathrm{Au} / \mathrm{YCeAl}$ suggests that the amount of Y-doped ceria phase, dispersed on alumina, could not provide enough active sites, while much more Au-ceria interfaces on $\mathrm{Au} / \mathrm{Ce}$ maximized active sites between $\mathrm{Au}$ and ceria. This suggestion corroborates above discussed role of preparation method of mixed oxide supports on activity of gold-based samples. However, after looking again at Figure $2 \mathrm{a}$, where all $\mathrm{Pd}$-containing samples were compared, this hypothesis does not seem relevant. The Pd/YCeAl catalyst exhibited superior activity, higher than that of $\mathrm{Pd} / \mathrm{Ce}$. Obviously, the nature of noble metal plays a very important role. The $\mathrm{Pd} / \mathrm{Ce}$ catalyst demonstrated lower activity then that of $\mathrm{Au} / \mathrm{Ce}$ (Figure $3 \mathrm{a}$ ) and this result is in agreement with the observed low temperature HC $\left(0.54 \mathrm{mmol} \cdot \mathrm{g}^{-1}\right.$ as compared to $0.43 \mathrm{mmol} \cdot \mathrm{g}^{-1}$, Table 3), e.g., a lower possibility of active oxygen supply. In all other cases, the performance of monometallic Au-based catalysts was inferior compared to Pd-based and bi-metallic $\mathrm{Pd}-\mathrm{Au}$ catalysts. The deposition of gold was carried out by deposition-precipitation. The affinity of gold particles to nucleate preferentially on ceria surface by applying this preparation method was taken into consideration in order to avoid as much as possible deposition over alumina. Indeed, XPS analysis showed higher dispersion of gold on the surface of $\mathrm{Au} / \mathrm{Ce}$. The comparison of the XPS derived atomic ratio (0.06) and the nominal one (0.0175) implied a gold enriched surface, while the respective ratios for $\mathrm{Au} / \mathrm{CeAl}$ and $\mathrm{Au} / \mathrm{YCeAl}$ were just as the nominal ratio. In contrast, an important feature of $\mathrm{Au} / \mathrm{Al}$ is the presence of gold with quite large particles size. This catalyst does not show any activity and this finding is not surprising. Gluhoi et al. [25] have also observed very low conversion of propene over $\mathrm{Au} / \mathrm{Al}_{2} \mathrm{O}_{3}$. The crucial impact of gold particles size on oxidation activity has been widely discussed [10]. Numerous studies have pointed out the role of highly dispersed gold particles stabilized over high surface area supports, in particular reducible oxides as $\mathrm{CeO}_{2}, \mathrm{Fe}_{2} \mathrm{O}_{3}, \mathrm{TiO}_{2}$, etc., to enhance VOCs oxidation activity.

However, the deposition of $\mathrm{Pd}$ on inert $\mathrm{Al}_{2} \mathrm{O}_{3}$ resulted in relatively high activity of $\mathrm{Pd} / \mathrm{Al}(85 \%$ conversion at $100{ }^{\circ} \mathrm{C}$ ). On the one hand, the explanation could be related to the ability of PdO to provide active oxygen. The $\mathrm{CBO}$ activity of $\mathrm{Au} / \mathrm{CeAl}$ and $\mathrm{Au} / \mathrm{YCeAl}$ is governed solely by enhanced active oxygen provision from affected by gold ceria or Y-doped ceria phase which is $30 \mathrm{wt} . \%$ only. Much better catalytic behavior in $\mathrm{CBO}$ of Pd-based catalysts originated from contribution to the oxidation activity of both Pd located on ceria or Y-doped ceria phase and Pd dispersed on alumina. The positive effect of Y-doping on oxygen supply from ceria was disclosed by XPS analysis (higher ratio $\mathrm{Ce}^{3+} / \mathrm{Ce}^{3+}+\mathrm{Ce}^{4+}$ ) and it agreed well with the observed superior activity of $\mathrm{Pd} / \mathrm{YCeAl}$ catalyst (Figure 2a). On the other hand, the hydrocarbon activation is also appreciable.

The role of gold and palladium on one side, and support on the other in both benzene and oxygen activation seems responsible for the differences in catalytic performance. As commented above, the role of gold for oxygen and benzene activation is via enhanced oxygen vacancies creation at ceria surface. Big gold particles on alumina do not contribute to the CBO activity. Concerning the high performance of Pd catalysts, Huang et al. have concluded that it can be related to the ability of PdO to provide oxygen and also to the participation of metallic Pd sites in the VOCs decomposition [43] and references therein. Hydrocarbon adsorption is generally found to occur at Pd surface through $\pi$ bonds and backdonation from the metal to the $\pi^{*}$-hydrocarbon orbitals [7] and references therein. Studying metal-promoted C-H activation, Roudesly et al. have commented that electron poor metals in high oxidation states may react with the electron rich arenes-the vacant $\mathrm{Pd}^{2+}$ orbitals will be attracted to the $\pi$-electron rich aromatic sites and the electron transfer will result in organic molecule oxidation and $\mathrm{Pd}^{0}$ formation, transferring by the oxidizing system back to its initial $\mathrm{Pd}^{2+}$ state [44]. Concerning benzene oxidation over zeolites supported Pd catalysts, Hea at al. have proposed initial $\mathrm{Pd}^{2+} \mathrm{O}^{2-}$ reduction by benzene followed by $\mathrm{Pd}^{0}$ oxidation with $\mathrm{O}_{2}$ from the stream and $\mathrm{Pd}^{2+} \mathrm{O}^{2-}$ recovering [45]. Such redox process with gas phase oxygen supply prevails for unreducible supports like alumina, whereas for reducible supports like ceria, the lattice oxygen from ceria surface layers could participate in the redox transfer $\mathrm{Pd}^{0} \leftrightarrow \mathrm{PdO}$. 
Differently from our previous finding of superior CBO activity of bimetallic Pd-Au catalysts in comparison with monometallic ones, in this study, the best performance was exhibited by Pd-based samples on alumina-supported ceria and particularly on alumina-supported Y-doped ceria. In addition to above commented redox transfer $\mathrm{Pd}^{0} \leftrightarrow \mathrm{PdO}$, the reason could be also higher surface concentration of Pd and $\mathrm{Ce}^{3+}$ in monometallic samples, evidenced by XPS analysis, as well as the presence of adsorbed superoxo species $\mathrm{O}_{2}{ }^{-}$close to the $\mathrm{Ce}^{4+}$ ions registered in EPR spectra. Additionally, in PXRD patterns of all Pd-containing samples no reflections due to the presence of $\mathrm{PdO}$ were detected, disclosing its high dispersion, while such a statement is not valid for gold on alumina. It is clear, that the catalytic performance is closely related to the dispersion of noble metal on unreducible supports. Chlala et al. have found higher activity in toluene conversions over palladium than over gold, supported on hydroxyapatite, due to the differences on noble metals particles size [46]. However, the contribution of reducible oxide on improved combustion activity is another very important issue. In spite of the high benzene conversion degree over $\mathrm{Pd} / \mathrm{Al}$, this sample does not attain complete oxidation of benzene even at $300{ }^{\circ} \mathrm{C}$. Analyzing the behavior of both Au and Pd-based monometallic samples on pure ceria, EPR spectra indicated formation of coke during the catalytic tests, that affected also negatively total benzene conversion. The modification of unreducible oxide with surface fraction of reducible one appeared favorable in present case. However, the reason for lower activity of both bimetallic formulations on $\mathrm{CeO}_{2} / \mathrm{Al}_{2} \mathrm{O}_{3}$ and $\mathrm{Y}$-doped $\mathrm{CeO}_{2} / \mathrm{Al}_{2} \mathrm{O}_{3}$ in comparison with that of Pd-based system is still not clear. We could hypothesize that modification of alumina by $30 \mathrm{wt} . \%$ ceria, respectively Y-doped ceria, is not enough to provide sufficient number active sites at the interface of gold and ceria for oxygen and $\mathrm{C}-\mathrm{H}$ bond activation. In contrast, catalytic performance of Pd-based catalysts is affected by both Pd located on ceria or Y-doped ceria phase and Pd dispersed on alumina. The deposition of $\mathrm{Pd}$ on the preliminary prepared $\mathrm{Au} / \mathrm{CeAl}$ and $\mathrm{Au} / \mathrm{YCeAl}$ limited the contact of $\mathrm{Pd}$ with ceria, because these sites were already occupied by gold. The main contribution of $\mathrm{Pd}$ is expected to be due to Pd/alumina interaction.

\section{Conclusions}

This study represents results of our efforts for optimization of catalyst composition from an economic point of view. Emphasis was placed on preparation of a suitable support able to stabilize small $\mathrm{Au}, \mathrm{Pd}$ or Pd-Au nanoparticles from one side and to create an optimal contact structure between them and the support on the other. Alumina-supported ceria $(30 \mathrm{wt} . \%)$ was prepared by impregnation or mechanical mixing and used as support of gold-based catalysts for CBO. Textural properties of mechanochemically mixed $\mathrm{CeO}_{2}-\mathrm{Al}_{2} \mathrm{O}_{3}$ in terms of surface area, pore volume and pore diameter affected positively the combustion activity and were selected for preparation of $\mathrm{Pd}$-based and $\mathrm{Pd}-\mathrm{Au}$ systems. Additionally, the favorable role of Y-doping of ceria in $\mathrm{CeO}_{2}-\mathrm{Al}_{2} \mathrm{O}_{3}$ mixed support on catalytic behavior of mono- and bimetallic Pd-Au catalysts was observed. It was related to improved mobility of oxygen in ceria surface layers. Superior activity exhibited Pd-based samples on alumina-supported ceria and particularly on alumina-supported Y-doped ceria. Redox transfer $\mathrm{Pd}^{0} \leftrightarrow \mathrm{PdO}$, higher surface concentration of $\mathrm{Pd}$ and $\mathrm{Ce}^{3+}$, evidenced by XPS analysis, as well as the presence of adsorbed superoxo species $\mathrm{O}_{2}{ }^{-}$close to the $\mathrm{Ce}^{4+}$ ions registered in EPR spectra contributed to the best performance. The potential of these catalytic materials to meet stringent emission regulations in an economical and effective way was disclosed.

Author Contributions: T.T. and L.I. writing the manuscript; T.T. preparation of the samples; P.P. catalytic tests and TPR measurements; Y.K. EPR analyses; A.M.V. XPS analyses; L.F.L. morphology analyses; G.A. PXRD analyses. All authors have read and agreed to the published version of the manuscript.

Funding: This research was funded by Bulgarian National Science Fund grant number KП-06-KOCT/4.

Acknowledgments: This article is based upon work from COST Action INDAIRPOLLNET CA17136, supported by COST (European Cooperation in Science and Technology). The authors acknowledge technical support provided by Nunzio Galli.

Conflicts of Interest: The authors declare no conflict of interest. 


\section{References}

1. Kamal, M.S.; Razzak, S.A.; Hossain, M.M. Catalytic oxidation of volatile organic compounds (VOCs)-A review. Atmos. Environ. 2016, 140, 117-134. [CrossRef]

2. He, C.; Cheng, J.; Zhang, X.; Douthwaite, M.; Pattisson, S.; Hao, Z. Recent advances in the catalytic oxidation of volatile organic compounds: A review based on pollutant sorts and sources. Chem. Rev. 2019, 119, 4471-4568. [CrossRef]

3. Zang, M.; Zhao, C.; Wang, Y.; Chen, S. A review of recent advances in catalytic combustion of VOCs on perovskite-type catalysts. J. Saudi Chem. Soc. 2019, 23, 645-654. [CrossRef]

4. Gelles, T.; Krishnamurthy, A.; Adebayo, B.; Rownaghi, A.; Rezaei, F. Abatement of gaseous volatile organic compounds: A material perspective. Catal. Today 2019. [CrossRef]

5. Ivanova, S.; Pérez, A.; Centeno, M.; Odriozola, J.A. Structured Catalysts for Volatile Organic Compound Removal. In New and Future Developments in Catalysis: Catalysis for Remediation and Environmental Concerns, 1st ed.; Suib, S., Ed.; Elsevier B.V.: Amsterdam, The Netherlands, 2013; pp. 233-256. [CrossRef]

6. Li, J.; Liu, H.; Deng, Y.; Liu, G.; Chen, Y.; Yang, J. Emerging nanostructured materials for the catalytic removal of volatile organic compounds. Nanotechnol. Rev. 2016, 5, 147-181. [CrossRef]

7. Liotta, L.F. Catalytic oxidation of volatile organic compounds on supported noble metals. Appl. Catal. B Environ. 2010, 100, 403-412. [CrossRef]

8. Barakat, T.; Rooke, J.C.; Tidahy, H.L.; Hosseini, M.; Cousin, R.; Lamonier, J.-F.; Giraudon, J.-M.; de Weireld, G.; $\mathrm{Su}$, B.-L.; Siffert, S. Noble-metal-based catalysts supported on zeolites and macro-mesoporous metal oxide supports for the total oxidation of volatile organic compounds. ChemSusChem 2011, 4, 1420-1430. [CrossRef]

9. Andreeva, D.; Tabakova, T.; Ilieva, L.; Naydenov, A.; Mehanjiev, D.; Abrashev, M.V. Nanosize gold catalysts promoted by vanadium oxide supported on titania and zirconia for complete benzene oxidation. Appl. Catal. A Gen. 2001, 209, 291-300. [CrossRef]

10. Scire, S.; Liotta, L.F. Supported gold catalysts for the total oxidation of volatile organic compounds. Appl. Catal. B Environ. 2012, 125, 222-246. [CrossRef]

11. Carabineiro, S.A.C.; Chen, X.; Martynyuk, O.; Bogdanchikova, N.; Avalos-Borja, M.; Pestryakov, A.; Tavares, P.B.; Órfão, J.J.M.; Pereira, M.F.R.; Figueiredo, J.L. Gold supported on metal oxides for volatile organic compounds total oxidation. Catal. Today 2015, 244, 103-114. [CrossRef]

12. Wang, Q.; Yeung, K.L.; Bañares, M.A. Ceria and its related materials for VOC catalytic combustion: A review. Catal. Today 2019. [CrossRef]

13. Chen, X.; Carabineiro, S.A.C.; Bastos, S.S.T.; Tavares, P.B.; Órfão, J.J.M.; Pereira, M.F.R.; Figueiredo, J.L. Catalytic oxidation of ethyl acetate on cerium-containing mixed oxides. Appl. Catal. A Gen. 2014, 472, 101-112. [CrossRef]

14. Scirè, S.; Minicò, S.; Crisafulli, C.; Satriano, C.; Pistone, A. Catalytic combustion of volatile organic compounds on gold/cerium oxide catalysts. Appl. Catal. B Environ. 2003, 40, 43-49. [CrossRef]

15. Scirè, S.; Riccobene, P.; Crisafulli, C. Ceria supported group IB metal catalysts for the combustion of volatile organic compounds and the preferential oxidation of CO. Appl. Catal. B Environ. 2010, 101, 109-117. [CrossRef]

16. Ilieva, L.; Petrova, P.; Liotta, L.F.; Sobczak, J.W.; Lisowski, W.; Kaszkur, Z.; Munteanu, G.; Tabakova, T. Gold catalysts on Y-doped ceria supports for complete benzene oxidation. Catalysts 2016, 6, 99. [CrossRef]

17. Xu, L.; Chen, D.; Qu, J.; Wang, L.; Tang, J.; Liu, H.; Yang, J. Replacement reaction-based synthesis of supported palladium catalysts with atomic dispersion for catalytic removal of benzene. J. Mater. Chem. A 2018, 6, 17032-17039. [CrossRef]

18. Weng, X.; Shi, B.; Liu, A.; Sun, J.; Xiong, Y.; Wan, H.; Zheng, S.; Dong, L.; Chen, Y.-W. Highly dispersed $\mathrm{Pd} /$ modified- $\mathrm{Al}_{2} \mathrm{O}_{3}$ catalyst on complete oxidation of toluene: Role of basic sites and mechanism insight. Appl. Surf. Sci. 2019, 497, 143747. [CrossRef]

19. Kim, S.C.; Shim, W.G. Properties and performance of Pd based catalysts for catalytic oxidation of volatile organic compounds. Appl. Catal. B Environ. 2009, 92, 429-436. [CrossRef]

20. Hosseini, M.; Barakat, T.; Cousin, R.; Aboukaïs, A.; Su, B.-L.; De Weireld, G.; Siffert, S. Catalytic performance of core-shell and alloy Pd-Au nanoparticles for total oxidation of VOC: The effect of metal deposition. Appl. Catal. B Environ. 2012, 111, 218-224. [CrossRef] 
21. Sankar, M.; Dimitratos, N.; Miedziak, P.J.; Wells, P.P.; Kiely, C.J.; Hutchings, G.J. Designing bimetallic catalysts for a green and sustainable future. Chem. Soc. Rev. 2012, 41, 8099-8139. [CrossRef]

22. Tabakova, T.; Ilieva, L.; Petrova, P.; Venezia, A.M.; Avdeev, G.; Zanella, R.; Karakirova, Y. Complete benzene oxidation over mono and bimetallic Au-Pd catalysts supported on Fe-modified ceria. Chem. Eng. J. 2015, 260, 133-141. [CrossRef]

23. Ilieva, L.; Venezia, A.M.; Petrova, P.; Pantaleo, G.; Liotta, L.F.; Zanella, R.; Kaszkur, Z.; Tabakova, T. Effect of $\mathrm{Y}$ modified ceria support in mono and bimetallic Pd-Au catalysts for complete benzene oxidation. Catalysts 2018, 8, 283. [CrossRef]

24. Centeno, M.A.; Paulis, M.; Montes, M.; Odriozola, J.A. Catalytic combustion of volatile organic compounds on $\mathrm{Au} / \mathrm{CeO}_{2} / \mathrm{Al}_{2} \mathrm{O}_{3}$ and $\mathrm{Au} / \mathrm{Al}_{2} \mathrm{O}_{3}$ catalysts. Appl. Catal. A Gen. 2002, 234, 65-78. [CrossRef]

25. Gluhoi, A.C.; Bogdanchikova, N.; Nieuwenhuys, B.E. The effect of different types of additives on the catalytic activity of $\mathrm{Au} / \mathrm{Al}_{2} \mathrm{O}_{3}$ in propene total oxidation: Transition metal oxides and ceria. J. Catal. 2005, 229, 154-162. [CrossRef]

26. Aznárez, A.; Korili, S.A.; Gil, A. The Promoting effect of cerium on the characteristics and catalytic performance of palladium supported on alumina pillared clays for the combustion of propene. Appl. Catal. A Gen. 2014, 474, 95-99. [CrossRef]

27. Sherwood, P.M.A. Practical Surface Analysis; Briggs, D., Seah, M.P., Eds.; Wiley: New York, NY, USA, 1990; pp. 555-585.

28. Reina, T.R.; Ivanova, S.; Idakiev, V.; Delgado, J.J.; Ivanov, I.; Tabakova, T.; Centeno, M.A.; Odriozola, J.A. Impact of $\mathrm{Ce}-\mathrm{Fe}$ synergism on the catalytic behavior of $\mathrm{Au} / \mathrm{CeO}_{2}-\mathrm{FeO}_{\mathrm{x}} / \mathrm{Al}_{2} \mathrm{O}_{3}$ for pure $\mathrm{H}_{2}$ production. Catal. Sci. Technol. 2013, 3, 779-787. [CrossRef]

29. Ilieva, L.; Petrova, P.; Pantaleo, G.; Zanella, R.; Sobczak, J.W.; Lisowski, W.; Kaszkur, Z.; Munteanu, G.; Yordanova, I.; Liotta, L.F.; et al. Alumina supported Au/Y-doped ceria catalysts for pure hydrogen production via PROX. Int. J. Hydrogen Energy 2019, 44, 233-245. [CrossRef]

30. Ilieva, L.; Petrova, P.; Pantaleo, G.; Zanella, R.; Sobczak, J.W.; Lisowski, W.; Ivanov, I.; Kaszkur, Z.; Liotta, L.F.; Venezia, A.M.; et al. Impact of ceria loading on the preferential $\mathrm{CO}$ oxidation over gold catalysts on $\mathrm{CeO}_{2} / \mathrm{Al}_{2} \mathrm{O}_{3}$ and Y-doped $\mathrm{CeO}_{2} / \mathrm{Al}_{2} \mathrm{O}_{3}$ supports prepared by mechanical mixing. Catal. Today 2019. [CrossRef]

31. Liotta, L.F.; Pantaleo, G.; Puleo, F.; Venezia, A.M. Au/CeO $2-S B A-15$ catalysts for CO oxidation: Effect of ceria loading on physicochemical properties and catalytic performances. Catal. Today 2012, 187, 10-19. [CrossRef]

32. Hosseini, M.; Siffert, S.; Tidahy, H.L.; Cousin, R.; Lamonier, J.-F.; Aboukais, A.; Vantomme, A.; Roussel, M.; $\mathrm{Su}, \mathrm{B}$.-L. Promotional effect of gold added to palladium supported on a new mesoporous $\mathrm{TiO}_{2}$ for total oxidation of volatile organic compounds. Catal. Today 2007, 122, 391-396. [CrossRef]

33. Menegazzo, F.; Burti, P.; Signoretto, M.; Manzoli, M.; Vankova, S.; Boccuzzi, F.; Pinna, F.; Strukul, G. Effect of the addition of $\mathrm{Au}$ in zirconia and ceria supported Pd catalysts for the direct synthesis of hydrogen peroxide. J. Catal. 2008, 257, 369-381. [CrossRef]

34. Sanchez, M.G.; Gazquez, J.L. Oxygen vacancy model in strong metal-support interaction. J. Catal. 1987, 104, 120-135. [CrossRef]

35. Laachir, A.; Perrichon, V.; Bardi, A.; Lamotte, J.; Catherine, E.; Lavalley, J.C.; El Faallah, J.; Hilaire, L.; Le Normand, F.; Quemere, E. Reduction of $\mathrm{CeO}_{2}$ by hydrogen. Magnetic susceptibility and Fourier-transform infrared, ultraviolet and X-ray photoelectron spectroscopy measurements. J. Chem. Soc. Faraday Trans. 1991, 87, 1601-1609. [CrossRef]

36. Gil, S.; Garcia-Vargas, J.M.; Liotta, L.F.; Pantaleo, G.; Ousmane, M.; Retailleau, L.; Giroir-Fendler, A. Catalytic Oxidation of Propene over Pd Catalysts Supported on $\mathrm{CeO}_{2}, \mathrm{TiO}_{2}, \mathrm{Al}_{2} \mathrm{O}_{3}$ and $\mathrm{M} / \mathrm{Al}_{2} \mathrm{O}_{3}$ Oxides $(\mathrm{M}=\mathrm{Ce}, \mathrm{Ti}$, $\mathrm{Fe}, \mathrm{Mn})$. Catalysts 2015, 5, 671-689. [CrossRef]

37. Green, U.; Aizanshtat, Z.; Ruthstein, S.; Cohen, H. Stable radicals formation in coals undergoing weathering: Effect of coal rank. Phys. Chem. Chem. Phys. 2012, 14, 13046-13052. [CrossRef] [PubMed]

38. Ge, L.; Chen, T.; Liu, Z.; Chen, F. The effect of gold loading on the catalytic oxidation performance of $\mathrm{CeO}_{2} / \mathrm{H}_{2} \mathrm{O}_{2}$ system. Catal. Today 2014, 224, 209-215. [CrossRef]

39. Aboukais, A.; Aouad, S.; Skaf, M.; Hany, S.; Labaki, M.; Cousin, R.; Abi-Aad, E. EPR investigation of the nature of oxygen species present on the surface of gold impregnated cerium oxide. Mater. Chem. Phys. 2016, 170, 285-293. [CrossRef] 
40. Xie, S.H.; Liu, Y.X.; Deng, J.G.; Zhao, X.T.; Yang, J.; Zhang, K.F.; Han, Z.; Dai, H.X. Three-dimensionally ordered macroporous $\mathrm{CeO}_{2}$-supported Pd@Co nanoparticles: Highly active catalysts for methane oxidation. J. Catal. 2016, 342, 17-26. [CrossRef]

41. Liu, Y.; Liu, B.; Wang, Q.; Li, C.; Hu, W.; Liu, Y.; Jing, P.; Zhao, W.; Zhang, J. Three-dimensionally ordered macroporous $\mathrm{Au} / \mathrm{CeO}_{2}-\mathrm{Co}_{3} \mathrm{O}_{4}$ catalysts with mesoporous walls for enhanced $\mathrm{CO}$ preferential oxidation in $\mathrm{H}_{2}$-rich gases. J. Catal. 2012, 296, 65-76. [CrossRef]

42. Bu, Y.; Chen, Y.; Jiang, G.; Hou, X.; Li, S.; Zhang, Z. Understanding of $\mathrm{Au}-\mathrm{CeO}_{2}$ interface and its role in catalytic oxidation of formaldehyde. Appl. Catal. B. Environ. 2020, 260, 118138. [CrossRef]

43. Huang, H.; Xu, Y.; Feng, Q.; Leung, D.Y.C. Low temperature catalytic oxidation of volatile organic compounds: A review. Catal. Sci. Technol. 2015, 5, 2649-2669. [CrossRef]

44. Roudesly, F.; Oble, J.; Poli, G. Metal-catalyzed CH activation/functionalization: The fundamentals. J. Mol. Catal. A 2017, 426, 275-296. [CrossRef]

45. Hea, C.; Li, J.; Li, P.; Chenga, J.; Haoa, Z.; Xu, Z.-P. Comprehensive investigation of Pd/ZSM-5/MCM-48 composite catalysts with enhanced activity and stability for benzene oxidation. Appl. Catal. B Environ. 2010, 96, 466-475. [CrossRef]

46. Chlala, D.; Labaki, M.; Giraudon, J.-M.; Gardoll, O.; Denicourt-Nowicki, A.; Roucoux, A.; Lamonier, J.-F. Toluene total oxidation over Pd and Au nanoparticles supported on hydroxyapatite. C.R. Chimie 2016, 19, 525-537. [CrossRef]

(C) 2020 by the authors. Licensee MDPI, Basel, Switzerland. This article is an open access article distributed under the terms and conditions of the Creative Commons Attribution (CC BY) license (http://creativecommons.org/licenses/by/4.0/). 